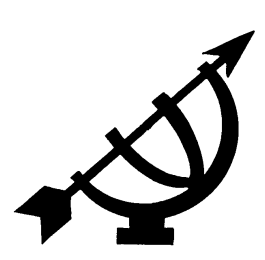

\title{
Reformation and/or Renaissance? A comparison between John Calvin's and Thabo Mbeki's ideas of renewal ${ }^{1}$
}

\author{
B.J. van der Walt, \\ School of Social Studies (Philosophy) \\ Potchefstroom University for CHE \\ POTCHEFSTROOM \\ E-mail: hannah@intekom.co.za
}

Abstract

Reformation and/or renaissance? A comparison between John Calvin's and Thabo Mbeki's ideas of renewal

This essay compares the differences and similarities between the European Renaissance $( \pm 1300- \pm 1600)$ and the African Renaissance in order to determine what an apposite Christian attitude would be. The first section describes the European Renaissance as a reaction to the Middle Ages and a return to the original sources of Western civilisation. Two different trends are distinguished, viz. classical humanism and evangelical humanism. The ideas of the great Renaissance thinker and evangelical humanist, John Calvin, about reformation receive special attention in this regard. He learned much from his contemporaries, but did so in a critical, independent way. From the five different Christian worldviews which crystallised during the Renaissance epoch, his Reformational worldview was the most strongly biblically founded one. The second main part of the essay first asks some critical questions about the African Renaissance and then provides a brief historical survey of past efforts at an African Renaissance, followed by an exposition and evaluation of Thabo Mbeki's ideas about an African Renaissance. The third main section of the essay poses the question as to what role Christianity can and should play in the African Renaissance. Similar to the attitude of Calvin, we should both learn from it and contribute to it from the perspective of a Christian worldview.

1 The impetus for this article was from a keynote address delivered at the First General Assembly of the World Reformed Fellowship, 23-26 September 2002, Muldersdrift, South Africa. 
The notion of the African Renaissance has become a central preoccupation of Thabo Mbeki, the South African president. He already claimed in 1998 that "Africa's time has come ... The new century must be an African century" (Mbeki, 1998:204). This claim has developed to the point where it is not simply a slogan any longer, and one has at this stage to examine the notion carefully so as to arrive at a clear idea as to what it constitutes. One also has to keep in mind that the present African Renaissance is not the first movement towards renewal. In which ways does it differ from or agree with the original European Renaissance? Can it learn something from its predecessor which altered Europe so dramatically between 1300 and 1600 ?

\section{A worldview approach}

Both the European and African Renaissance movements are complex phenomena, both being periods of deep cultural crisis in which the immediate past is rejected and something new and essentially better anticipated.

There are many different interpretations of the European Renaissance (cf. Rienstra, 1981) and the same applies for the African Renaissance (see Liebenberg, 1998). The contention underlying this article is that during periods of transition people are usually in search for a new worldview as previous worldviews do not make sense of reality any more, because they cannot clearly indicate one's place and task in a changed environment. One's worldview, therefore, has to be adapted or even replaced by a totally new worldview to provide guidance. A recent example would be the rejection of the apartheid (or Christian-national) worldview in South Africa.

\section{The European Renaissance: background and essential nature}

\subsection{The Medieval background}

As Bouwsma (1988:64) correctly indicates, the Middle Ages inherited two different cultures from antiquity: pagan Hellenistic and Biblical Hebraic, both of which were forced into an uneasy synthesis. At the height of the Middle Ages the relationship between pagan Hellenistic and Roman culture and Biblical Hebrew and New Testament culture was viewed as the sacred superseding the secular. The lower, natural sphere was essentially a preamble to be perfected in the higher sphere of grace.

In real life the tension inherent in this worldview was never resolved. The choice came down to either a vita contemplativa or a secular life. 
Because of the false dualism inherent in the Thomistic, Medieval worldview, the above choice could not really resolve the tension. It has now become a truism that one of the major breakthroughs of the Renaissance and especially the Reformation was that it challenged this compartmentalising Medieval worldview. McGrath (1988:19-25) mentions at least three important thrusts in this regard: the rise of doctrinal pluralism, growing religious piety among the laity, and the challenge to the authority of Medieval Christianity.

\subsection{Nature of the Renaissance}

The Renaissance, covering approximately the period from the 14th to the beginning of the 17th century, can be characterised in many ways. It has been called "The Age of Adventure" by De Santillana (1956) because of the many discoveries that characterised it. Innovations associated with the period covered areas (cf. Störig, 1969:16, 17) ranging from the geographical, military, astronomical to the world of communication (the printing press) and literature and philosophy (the emergence of the philosophy of Humanism being of paramount importance), from the scientific to the political and economic (development of capitalism, the breakdown of the feudal system) to the religious (the Reformation and Protestantism with a concomitant impact on Catholicism).

Philosophically speaking the Renaissance was a heterogeneous movement. Many age-old philosophies were revived, like Platonism, neoPlatonism, Stoicism, Epicurianism, Aristotelism, etc. (cf. Van der Walt, 1991c:230-238), but no single philosophical idea dominated - the Renaissance lacked a coherent philosophy (cf. Popkin, 1966).

With the Medieval worldview no longer tenable, a new worldview had to develop to integrate the new developments into a coherent whole. The French word "renaissance" (rebirth), albeit applied long after the epoch had gone, encapsulates the essence of what thinkers of the period themselves categorised as "return", "restoration", "revival", "reawakening", "reflowering", etc. A dominant trend of early Renaissance thought was a return to what was regarded as a better time than the recent Middle Ages, a way of looking back to antiquity for inspiration and instruction, the slogan being ad fontes: (back) to the (original) sources (of Western civilisation). The emphasis on studia humanitas or studia humaniora centred strongly in rhetoric. The rhetorical tradition has a long history, which was revived during the Renaissance. Medieval scholasticism depended on logic, but during the Renaissance, scholasticism was viewed as too theoretical, abstract, sterile and removed from real practical life. Rhetoric, the art of persuasion, took its place. Renaissance man viewed man as being a passionate, active, social and practical 
rather than a purely intellectual being. (An important rhetorical virtue was decorum, adaptation to one's time and audience.)

John Calvin (1509-1564) was imbued with this same spirit. He was not an analyst or a systematic thinker in the first place, but a rhetorician. He always combined the Renaissance idea of eruditio (erudition) with persuasio (persuasion) by asking for what purpose or what benefit something was said or written. Calvin's writings were essentially intended to be useful: to teach, to move, to inspire or persuade. He did not conceive of his task to be a minister (he was never ordained) or to provide a new exposition of theology (he called his Institutes an introduction to a Christian philosophy).

\subsection{Two different trends}

Two different trends presented themselves in the context of a return to the past. In his desire to return to the past, Calvin - and many other Protestant Reformers - was a true Renaissance figure, but the question about which sources of antiquity should be regarded as authoritative made a difference. In classical humanism, the classical works of pagan Roman and Greek thought predominated. This was very evident in Italy, the cradle of the Renaissance, usually called the Southern Renaissance. It was not primarily the philosophical substance of these writings that was admired, but the literary, artistic and rhetorical value embedded in them.

In spite of the fact that the Northern Renaissance learned much from the Renaissance in Italy, these northern thinkers had a different emphasis. Estep (1986:45 ff.) indicates how, from its earliest days (cf. the devotio moderna or modern devotion) Northern Renaissance humanists were wedded to a deep religious quest preparing the way for the 16th century Reformation, as the intention of these Biblical or evangelical humanists was not in the first place to return to the pagan, but to the Christian sources of antiquity, viz. the Church Fathers (patres) and ultimately to the Bible, the Word of God itself. The vision of the Reformers can be summed up in the Latin slogan: Christianissimus renascens.

It is very important to distinguish between classical and the Biblical humanists, because the contemporary word "humanist" or "humanism" has a quite different connotation, being interpreted as meaning an antireligious philosophy (even atheism) together with the affirmation of man's autonomy. Some Renaissance humanists were sceptical about certain aspects of ecclesiastical life and Medieval scholasticism, tending towards moralism, but they were not anti-Christian (cf. Rienstra, 1981). A clear difference can, however, be discerned between classical and evangelical humanism (cf. Van der Walt, 1991a) in that the former was pre-eminently 
in favour of a renaissance of ancient pagan literature (the oratores et poetae), while the latter's aim was the renewal of Christian piety (pietas). ${ }^{2}$

\subsection{Repristination impossible}

The ideal of both types of humanists had been to return to the past, and notions of history are of central importance in such a context. Many Renaissance thinkers adhered to a cyclical view of history as a process of birth, growth and decline. The Middle Ages had been a dark interval between two ages of light. Calvin's own view was that with the Reformation nothing new had occurred, no radical change had taken place except for the renewal of the ancient form of the church, a recovery from a period of decline, a return to a happier state. Such a cyclical view of history assisted Calvin's positive treatment of antiquity and promised success for his contemporary reform movement. He did sometimes realise that this (pagan) idea of cyclical time and history was at odds with the linear concept of Judaism and Christianity, for instance, when he realised that a perpetuation of the early apostolic age might well be inappropriate in the 16th century, but he did not make explicit the consequences of a view that improvement of the church might take another form than a return to its origins (for the many dangers of Christian primitivism, see Van der Walt, 1991d:285-286).

The classical humanists of the Renaissance eventually encountered an identical problem. Because they were separated by nearly 2000 years from classical antiquity, it proved to be impossible to turn the clock back.

2 McGrath (1988:45-48) provides the following list of the differences between the Reformers and the classical humanists:

- In their attitude toward Scholastic theology the humanists' rejection was based on its unintelligibility and inelegance, while the Reformers rejected it because it was fundamentally wrong.

- To the humanists the authority of Scripture was based on its eloquence, simplicity and antiquity, while for the Reformers it was the Word of God.

- The humanists appreciated the writings of the Church Fathers because of their antiquity and elegance. The Reformers accepted them because they were reliable interpreters of the Bible.

- Education, according to the humanists, was a cultural process to develop the human being for the service of his fellowmen. The Reformers, on the other hand, emphasised religious education in the service of God.

- The humanists were concerned with rhetoric in order to promote both written and spoken eloquence, while the intention of the Reformers was to promote their religious ideas by means of eloquence. 


\subsection{A vital difference}

The Medievals perceived and experienced a disjuncture between the secular and the sacred and tried to transform them in the direction of a unity. The result, however, was that the Gospel, the Word of God lost its uniqueness, authority and transforming power. Essentially the evangelical humanists or Reformers agreed with their classical colleagues in their rejection of the Medieval compartmentalisation between Christian faith (or grace) and worldly endeavours (nature). There is, however, a vital difference. Whereas classical humanists secularised the sacred, the Biblical humanists or Reformers sacralised the secular. This does not mean that they tried to put an ecclesiastical stamp on "worldly" affairs the Reformers propagated a new (third) perspective, maintaining that in the office of believer we should serve God and promote his glory in every area of life.

\subsection{John Calvin as an example}

This viewpoint was probably best exemplified in the work of Calvin, whom one could define as a seeker and a master. The Calvin with whom most of us are acquainted is usually an artificial creature designed by his Calvinist followers. The popular picture of this great Renaissance man is often more hagiographical than historical - he only read the Bible and was influenced by the Word of God alone! He was not a child of his times, but a kind of 16th century Melchizedek appearing form nowhere. The real, historical Calvin, however, was a Renaissance man, a humanist, not only in his youth - he remained in major ways a humanist of the late Renaissance.

Of the many things he learned from his spiritual and intellectual environment one could mention his desire to return to the original sources of Christianity (ad fontes); the ethical and practical character of his teaching; the way in which he returned to Scripture itself. The ways in which Calvin applied humanistic hermeneutics to an understanding of the Bible required that the interpreter should respect the intention of the author; the books of the Bible should be understood as wholes and in the context of the author's purpose; obscure passages should be clarified by comparing them with those of which the meaning is clear; there should be a recognition that Biblical texts had been assembled and transmitted by fallible human beings over many centuries, and it should be kept in mind that different sections of the Bible had been written in different times. Finally, one should take cognisance of Calvin's rejection of scholastic theology in favour of a simple Christian philosophy or what we will today call a Christian worldview. 
But, as Ganoczy $(1987: 180,181)$ correctly argues, Calvin was not only a seeker who learned much from his predecessors and contemporaries. In the end he was a master, because he rethought, reformulated and reorganised the material drawn from the different sources and submitted it all to the supreme judgement of the Scriptures. For him humanism was not an end in itself, it simply helped him to support reform. In an earlier publication on Calvin and classical philosophy, Partee (1977:146) arrived at a similar conclusion about the way that Calvin employed Greek and Roman philosophy: He used them as illustrations of the truth rather than as guides to it.

\subsection{Five different models for reformation}

One should not ignore the importance of the social and political context of the 16th century Reformation. ${ }^{3}$ The Reformers often allied themselves with the political powers in order to succeed in their programmes of reform. However, our focus in this article is on the different backgrounds rooted in different worldviews.

A total of five different worldviews crystallised during the Renaissance (for details, see Van der Walt, 1991b:159 ff.). Each one of these held a different perspective on the central question of how a Christian should relate to the so-called secular world of trade, politics, education, etc.:

- The humanist worldview: The Christian of the world. (The key word is equality, there is no radical difference.)

- The Anabaptist worldview: The Christian against the world. (The key word is opposition, or radical difference.)

- The Lutheran worldview: The Christian beside the world. (The key word is parallelism, no contact, while both have legitimacy.)

- The Catholic worldview: The Christian above the world. (The key word is perfection, the Christian completes what is already present in the world.)

3 Essentially the notion of reform during the Renaissance was not something new in history - during the Middle Ages some efforts at reform occurred (Van der Walt, 1994: 322-323) and different reform movements manifested during the Renaissance. Apart from the classical humanists and Calvin, the Lutheran and Anabaptist (or radical) reformations should be mentioned. We will not deal separately with the so-called Counter Reformation, initiated by the Catholic Church, especially at the Council of Trent (1545), because it represented basically the same worldview as that of the Middle Ages, already explained above. 
- The Reformed worldview: The Christian in the world. (The key word is transformation of the world.) The Calvinist (or adherent of a Reformational worldview) differed from all the preceding Christians in that he believed a Christian's responsibility includes his/her direct involvement in socio-political life to be renewed and transformed.

This last worldview is, to my mind, the best and also the Biblically founded worldview. Three important remarks about the name of this worldview are the following:

- Firstly, Reformational does not mean Reformed churches, because a worldview, as the word suggests, is something much broader than an ecclesiastical confession, and additionally, Reformed churches - this is my sad experience - often no longer adhere to a Reformational worldview.

- Secondly, this is no attempt at canonising John Calvin. In spite of the fact that the broad outlines of his radical Christian worldview are acceptable, he has definitely not spoken the last or final word (cf. Van der Walt, 1987:244-252 for a critique).

- Thirdly, in the light of the previous remark, the word Reformational is preferred to the word Calvinism to indicate a worldview not based on a fallible human being's ideas but based on God's revelation and a woldview which has to be reformed continuously.

\subsection{Conclusion about the 16th century Renaissance}

The title of this article ("Reformation and/or Renaissance?") leads one to consider whether Reformation and Renaissance should go together or should present a choice. There has been an attempt to indicate that Reformation and Renaissance do not necessarily exclude each other: the Reformation was a movement within the broader epoch of the Renaissance. In no way could Calvin have become a Reformer of such crucial influence without the context of the Renaissance, while at the same time he made a reciprocal Christian contribution to the Renaissance. It could be postulated that Christians should adopt the same attitude towards the present African Renaissance: learning from it what we can, but also trying to make a unique Christian contribution towards its advancement.

\section{The African Renaissance}

Since 1994 there has been an endless volley of buzz words unleashed upon us: "masakhane", "ubuntu", "reconstruction and development", "reconciliation and transformation:, "a people-centred society" and so forth. 
The latest is the concept of the "African Renaissance", the word with perhaps the strongest bandwagon effect within the lexicon of the new South Africa. 4

Since president Mbeki raised his clarion call "The African renaissance is upon us" (1998a), there has been an African Renaissance Conference in September 1998 (see Makgoba, 1999), and many other gatherings, numerous deliberations have taken place, many articles and books have been written - all devoted to the renaissance of our continent. An African Renaissance Institute has been established. The African Renaissance has indeed become a rallying cry for people working in different spheres of cultural, social, economic and political life. It has already attracted the attention of not only leaders, politicians and economists, but also of Christian theologians from outside South Africa (cf. Bediako, 2001; Kombo, 2000; Mana, 2001 and Paris, 2001).

\subsection{Critical questions}

But not everyone seems willing to climb on the bandwagon. Critical questions like the following are being asked:

- Is the African Renaissance more than sloganeering and empty rhetoric posing as profundity and originality?

- Is it simply another instance of doublespeak, an attempt to cover up the real, pressing problems of African by vilifying the outside world and romanticising the African past?

- Is Mbeki simply a visionary, a dreamer, an optimist, a romantic, an idealist or is he a realist when he says that "Africa's time has come ... The new century must be an African century"? (Mbeki, 1998:204).

In other words, is there real substance to the idea that there is something new in Africa? Have the Roman Pliny's words become a reality: Ex Africa semper aliquid novi (something new always comes from Africa)?

Mzamane (2001) correctly asks what this Renaissance is, and what is particularly African about it. Liebenberg (1998) considers three possibilities:

$4 \quad$ Since the writing of this article, the latest buzz words have become NEPAD and the African Union - both practical processes aimed at realising this dream. The African Union was established on 9 July 2002 in Durban with Mbeki as its first president. 
- The African Renaissance can be an invented myth, the search for a collective identity, a reclaiming of Africa's supposed glorious past as a means of arriving at a better future.

- Or is the African Renaissance simply a mobilising tool for economic and political development? If so, democratisation, peace, stability and the integration into the global economy are at the heart of this Renaissance (see footnote 4 about NEPAD).

- Or is the African Renaissance a vital lie for the entrenchment and enhancement of the elite, an elite plot to recruit the poor masses into neo-liberal, multiparty politics and economic globalisation? If Africa is not ready, globalisation will only benefit the already rich elite. Globalisation is Janus-faced, and the simplistic acceptance of globalisation as both inevitable and beneficial is, to say the least, dangerous.

Critical questions like these should inform the consideration of the essence of the African Renaissance, which is, like its European forebear, a multi-faceted, historically evolving process.

\subsection{A historical irony}

Ironically the revival that the European Renaissance brought about contributed significantly to a Dark Age elsewhere in the world. The "discovery" of the "New World" led to the extermination of many of its indigenous peoples, and the vast expansion of the slave trade from Africa (1520-1870) relocated these peoples as labourers to the New World. Apart from slavery, the colonisation of the continent (1885-1960) led to the plundering of Africa's natural resources and the decimation of its cultures in the name of Western "civilisation". Slavery, colonialism and neo-colonialism (after independence) have all been more devastating than one can begin to imagine. Africa was not born a dark continent, but was made a dark continent, a Dark Age that has lasted for at least four centuries. Today Africa is still regarded as a dark continent, primarily known for its bad news. Conflicts, coups, corruption, dictatorships, genocides, aids, famines, natural disasters, etc. dominate what the world hears about our continent. In the global view Africa is written off as having little significance other than being a very secondary market for goods and ideas from elsewhere. No wonder that the word "Afropessimism" has established itself firmly.

\subsection{A brief historical review}

History testifies that Africans have long been dissatisfied with the state of their continent. The following words should be kept in mind: 
In reflecting on the African Renaissance, mere episodes must not be taken for the totality of the phenomenon. The African Renaissance is not a single event but a process long begun but far from finished. There have been many episodes, spanning several generations, in the rise of the Africans universally from the forces that put them down, many episodes in their unfolding culture of liberation (Mzamane, 2001).

A few flashes from history should suffice to illustrate this statement:

\section{- The rebellion of African slaves in the Americas and the Caribbean}

The rebellion in Haiti (1751-1757 and again in 1791) eventually led to the abolition of slavery (1793) and the independence of Haiti (1804). In America different slave revolts finally led to a constitution forbidding slavery in California in 1848 and later on in other parts of America.

\section{- Pan-Africanism}

The breeding ground of this movement was not Africa but the Africans in diaspora. The crushing slavery in the New World created a yearning among Africans in the Americas for their ancestral homelands. This resulted in the establishment of both Sierra Leone (in 1787) and Liberia (in 1847) as refuges for freed slaves.

The Pan African Movement also created African scholarship that challenged racist notions in the West, namely that Africans are by nature inferior beings. Apart from that it also organised a series of important congresses after the Berlin Congresses (1884-85) that carved up Africa among the European powers. The first and second were held in 1892 (Chicago) and 1919 (Paris). At the third Pan African Congress (Paris, 1921) the Pan African Manifesto (a precursor to the Organisation of African Unity Charter) was accepted. The sense of solidarity engendered by the Pan African Movement led to a greater interaction between the African people in the New World and on the continent. It also propagated the idea of one, unified Africa, and helped to inspire many nationalists fighting for the independence of their countries. The African National Congress, founded in 1912, is one of the oldest organisations of Pan African character and persuasion. Important figures in the Pan African Movement were both figures from outside Africa (like W.E.B. du Bois and Marcus Garvey) and inside (Kwame Nkrumah).

\section{- The Harlem Renaissance}

This movement blossomed in the 1920s. It was largely a cultural movement in the spirit of Pan-Africanism. Except for older themes like African solidarity and liberation, it also aspired to self-expression because the cultural space of Africans had been invaded by the West. It 
provided literary and artistic models people in different parts of Africa, including South Africa, could emulate. By reaching back to their African roots, they could assert their identity. Concrete examples are storytelling, Negro spirituals, blues and jazz.

\section{- Négritude}

The scene shifted from Harlem to Paris in the 1930s, to the Négritudemovement, aiming at psychological and cultural emancipation from European domination as a prerequisite for political liberation of the Africans universally. Leaders of this movement, like Aimé Césaire and Leopold Sedar Senghor championed African customs and traditions that had long been ridiculed by Europeans. They glorified the past, implying that Africa, which was great in the past, would be great again. Their discourse was anti-colonial and critical of Western culture's cold, impersonal and individualistic ways. However, they also portrayed an accommodating vision for the future of a world enriched by cultures from different countries. Apart from cultural awakening and political emancipation, Négritude did not emphasise economic development and technological advancement as Mbeki has been doing in the latest form of an African Renaissance.

\section{- The post-World-War II period}

During this period most African countries experienced liberation and independence from the European colonisers, meaning that Pan-Africanism finally achieved one of its goals. The other goal of African unity did not fully realise, because the Organisation of African Unity (formed in 1963) proved to be a rather ineffective collection of nation states.

The United States, during the 1950s and 1960s, was a place of turbulence and violence as a result of the Black Power and Civil Rights movements. In South Africa we saw the rise of the Black Consciousness Movement under the leadership of S. Biko and others.

\section{- The post-independence period}

The epic story of the rise of a once-enslaved people across the globe continued in this period. The time after independence was littered with renaissance efforts by the leaders of the new African states. Senghor promoted African socialism, Kaunda African humanism, Nkrumah consciencism, Kenyatta haraambe ("let us pull together"), and Nyerere ujamaa (village collectivisation). Some countries preferred Marxism while others espoused Capitalism as ideology.

At best these efforts succeeded partially and, at worst, failed miserably. The old colonial flags were lowered and new ones raised, but in fact very 
little changed. The litany of Africa's social, political and economic woes became endless. Stagnation is today everywhere and the power syndrome is destroying the continent country by country. The terrible suffering in the Africa of today is certainly not only caused by external enemies but also from within. It is not preposterous to say that all the features of classical tragedy can be seen in the modern African state.

\section{- The last decade of the 20th century}

The beginning of the 1990s introduced a new move of democratic transitions in sub-Saharan Africa which led to new optimism. The Cold War ended and after decades of stagnation economic performance improved markedly. (Average growth increased from about 1\% in 1992 to about $5 \%$ in 1997.) However, recent events in this region have given fresh cause for concern.

Following this brief overview of the different phases in the African Renaissance, the question arises as to what must be different about the current efforts to re-ignite the African Renaissance. What should be done differently to make this century truly "the African century"?

\subsection{Mbeki on the African Renaissance}

President Mbeki has gone further than any other African head of state by developing a plan for Africa's political, social and economic recovery. His vision of an African Renaissance is not a romantic or numinous idea. It was concretised in the Millennium Partnership for African Recovery Programme (MAP), the New African Initiative and the recently established New Partnership for Africa's Development (NEPAD) as well as the soon to be established African Union which will replace the old Organisation for African Unity. He has a multi-faceted programme in mind, as will be clear from the following exposition.

\section{A renaissance}

There is a remarkable similarity between the words Mbeki uses to describe his African Renaissance and the terms used in the European Renaissance already described. Throughout his book (1998) and his different speeches (1998a, 1998b, 1999, 2000a, 2000b, 2001, 2002) we find words like "rebirth", "re-awakening", "revival", "restoration", "reappearance". He clearly has the rebirth of Africa in mind. As we will soon see, his vision includes a return to Africa's past. But, as had been the case in Europe, especially within the later Renaissance, it is also futureoriented.

One of Mbeki's (1998) central themes in his speech at the African Renaissance Conference was: "Yesterday is a foreign country - to- 
morrow belongs to us." He thus sees the Renaissance of today - like the European one about 500 years ago - as a period of transition.

\section{An African Renaissance}

Mbeki clearly visualises an African Renaissance. Ten grand themes occur in most of his speeches:

\section{- Politics}

Mbeki over and over again emphasises that without responsible, accountable, transparent, good democratic government, there can be no African Renaissance. Human rights are therefore important.

\section{- Society}

Mbeki envisages a people-centred society in which all the interests of the masses are promoted rather than the acquisition of power of the elite. He is very concerned about the poor, women's status and the youth.

\section{- Economics}

One of the most important differences between previous renaissance efforts and Mbeki's is that they shared the common failing of not prioritising economics as a principal arena of struggle. According to Mbeki, economic development is a key factor. Democracy, for instance, can not be achieved when attention is not paid to the plight of the majority of Africans living in abject poverty and dehumanising conditions. More or less accepting the capitalist model, he is not uncritical. He calls "the market" the modern God, a supernatural phenomenon to whose dictates everything human must bow in a spirit of powerlessness. Interventions are made by the World Trade Organisation, the International Monetary Fund and the World Bank. It is our responsibility to question the nature and purpose of their interventions.

\section{- Peace, tolerance, reconciliation}

Conflicts of ethnical and religious nature undermine democracy and economic development. The African Renaissance is only possible in conditions of lasting peace and stability, a Pax Africana.

\section{- Development and self-reliance}

Instead of exporting Africa's immense mineral and other natural resources as raw materials, which only benefit the outside world, they should be processed inside the continent. Africa also relies too much on luxury imported goods. 
Closely connected with his idea of greater self-reliance is the motto that we should look to African solutions for African problems. This does not imply that Mbeki sees no role for the international world in the development of Africa. What it does mean is that African ownership of the African Renaissance is vital for its success.

\section{- Leadership}

Because in many African countries we have leaders who looted their countries on a scale colonial rulers would have envied, there is a vast need for real servant leaders who are committed to defending the interests of the people and not their own, who will refrain from corrupt practices and the abuse of power for self-interest.

\section{- Communication and information technology}

The necessity for radical change in this area is stressed by Mbeki, because without it many other facets of the Renaissance will remain a pipe-dream and Africa's permanent global marginalisation will be a fact.

\section{- Closer co-operation between African countries}

When Africa was divided between the different Europeans colonisers, divisive and arbitrary borders were the result. These are still today perpetuated by African leaders themselves, and remain a root cause for internecine strife and warfare.

\section{- Greater international co-operation}

Mbeki has done an excellent job of putting Africa higher on the international agenda. He is pushing relentlessly for the so-called G8 Western countries to agree that Africa constitutes the principal development challenge in the world, while at the same time he is not uncritical about the process of globalisation.

\section{- Culture}

This is a final feature of Mbeki's programme for an African Renaissance that he very often includes in his speeches. The rebirth he envisages includes a reclaiming of the African history, culture and heritage in order to challenge the Western stereotypes of Africa and the Africans. The revival of African history and culture will help us to develop a sense of pride and confidence in ourselves that we can succeed. Usually Mbeki will mention inspiring events from the past, like ancient African civilisations (e.g. Egypt) or great Medieval kingdoms (Akana, Mali and Monomotapa). Because slavery, colonialism, neo-colonialism and the present marginalisation of Africa have seriously damaged our souls, our task is that of a rediscovery of our own souls to restore our self-esteem. 
But Western cultural imperialism is not only a problem of yesterday. We still easily succumb to a Coca-Cola culture at the expense of our own culture and identity. A difficult question is how African countries can open their doors to Western products and capital, on the one hand, and on the other hand, keep out the invidious cultural baggage that accompanies capitalism and consumerism.

If I understand Mbeki correctly, he is not advocating a simple return to the past, nor is he trying to achieve an opportunistic mélange of the traditional and the modern. He is attempting to identify the valuable in traditional African worldviews and to build the future on the foundation of these values.

\subsection{Summary: an inward, continental and global look}

Landsberg and Hlope (1999) summarise Mbeki's African Renaissance ideals in the following three points:

\section{- A look inward and at the past}

Because the identity, worth and dignity of the African peoples have been trampled upon by both colonialism and apartheid, we have to look at our past heritage to recover our own identity and self-esteem in the present. Some might well regard this talk about culture as conservative or retrogressive, but I do not agree. Cultural identity and pride are prerequisites to inspire and sustain democracy and economic development. 5

\section{- A continental look}

In the second place, the African Renaissance is a departure from the hostile policy (the hallmark of the apartheid regime) towards other African countries. It signals a more neighbourly policy towards the rest of the continent. It grew out of the realisation that South Africa cannot itself succeed when it is surrounded by poor, underdeveloped countries. It is also stimulated by the belief that South Africa can be a catalyst to effect prosperity in Africa.

\section{- A global look}

Lastly, as already stated above, economic development is of vital importance and in the contemporary world this can only be achieved by integration into the global market.

5 This point is also emphasised by the Ghanaian philosopher, Kwame Gyekye, in his excellent book Tradition and modernity (1997), especially in its last two chapters (p. 217-297). 


\subsection{A brief evaluation}

Let me mention three reasons why I personally consider Mbeki's efforts laudable.

- Because Afro-pessimism as a contagious disease paralyses, I admire his optimism. He firmly believes that, if Africa could overcome slavery, colonialism, neo-colonialism and apartheid, it can also be victorious in its struggle against present challenges. Mbeki is a visionary and the vision he offers is worthy of our best efforts.

- But Mbeki is also a realist. I appreciate his realism when he emphasises that none of what is visualised in the African Renaissance will come about on its own, simply through a repetition of its objectives. Giving visible shape to the vision will ask concerted effort and very hard work.

- In the third place I like his critical approach. He speaks convincingly because he does not gloss over all of Africa's problems, like underdevelopment, bad leadership, corruption, disease, famines, etc. He openly confesses that Africa's problems were not only caused by colonial powers, but also by Africans themselves. He challenges the scape-goating and complacency which blames all the continent's ills on foreigners without accepting blame or responsibility themselves. He openly criticises the abuse of power and the cancer of selfenrichment by corrupt means of many African leaders. He rejects the culture in Africa that "brothers should not criticise each other".

Some serious hurdles will, however, have to be overcome - both inside and outside the continent - to realise the African Renaissance. Will the necessary foreign investments from the outside world be obtained? This will to a large extent depend on whether African leaders are willing to stop their abuse of power and self-enrichment to rule in a responsible, accountable way. Taking these two facts into account, the likely outcome will be that some countries will get their house in order, but that in others the retardation and underdevelopment will continue.

\subsection{Similarities and differences}

It will not be difficult to enumerate many similarities between the previous European Renaissance and the present African Renaissance. Both of them started because of dissatisfaction with the "dark times" experienced. Both did not occur suddenly, but were processes of transition spanning centuries. Both tried to look backward to be able to go into the future. Both entailed a discovery of what it means to be human, to be liberated from oppression. 
But, because these two renaissances occurred at historically different times and are also geographically separated there are great differences too.

One of these is that during the approximately 500 years that separate us from Renaissance and Reformation, Western culture has changed radically. The moderate form of humanism of the Renaissance developed into anti-religious secularism. The characteristics of the secularist worldview are that God's existence is denied. Even if He should exist, his existence does not really matter and has no relevance for human affairs - especially in public life. When God is declared dead, his will (as expressed in his commandments) does not have any claim on us. Man has become autonomous, creating his own standards, values, norms and guidelines according to which life is organised. Through the use of an idolised reason, man has become the creator of his own destiny. The age-old sin of man, viz. the desire to become god himself, already described at the beginning of the Bible, has become a fact in Western culture. Western secularism has today infiltrated the non-Western world, Africa included. In the public life of politics, economics, education, etc. religion of whatever kind is not welcome (cf. Van der Walt, 1999a, 2001).

We should therefore not be surprised when President Mbeki does not mention a possible role for any kind of religion or worldview in his African Renaissance. He may be a Christian, but he clearly does not see the relevance of Christianity for the burning issues of Africa. It may also be that, because there are so many religions in South Africa, as head of state he cautiously steers clear of the topic. Whatever the case, the fact remains that it is difficult to pinpoint the worldview assumptions underlying his ideas about an African Renaissance. Let us consider the possibilities.

From his bibliographical sketch (Mbeki, 1998:i-xxii) we can deduce that during his formative years Mbeki got to know both the Western capitalist and the socialist worldviews. He first obtained a B.A. (1965) and M.A.degree (1966), both majoring in economics, from the University of Sussex in the United Kingdom. Then he studied at the Institute of Social Studies in Moscow. He was also influenced by the socialist ideas of the South African Communist Party. After South Africa's independence (1994), these two trends became visible first in the Reconstruction and Development Programme or RDP (1994) and then in the Growth Employment and Redistribution Programme or GEAR (1996), which not only replaced the more socialist-oriented RDP, but was built on a capitalist, free-market worldview. The new South African Constitution (1996) also reflects a Western, liberal-democratic and not an African, communalist worldview. 
While Mbeki's speeches on the African Renaissance still contained many references in appreciation of traditional African culture, the "successor" of the African Renaissance, NEPAD, seems to be a more or less purely politico-economic issue. I am afraid that eventually NEPAD will be so strongly influenced by the economically powerful Western G8-countries, the World Bank and the International Monetary Fund that very little place will be left for a genuinely African Renaissance.

From the fact that, apart from other religious leaders, a sangoma was asked to perform a traditional ritual at Mbeki's inanguration as president, some like to believe that he is trying to reconcile traditional African faith with Western relativistic postmodernism. Personally I do not detect any postmodern worldview influence at this occasion. Africans are usually more inclusive in their religious attitudes. Furthermore, for the new head of a multireligious state this can simply be considered an appropriate gesture.

My preliminary conclusion is that the worldview behind the African Renaissance (including its successors, like MAP and NEPAD) is not the African traditional worldview, neither Christianity or postmodernism, but secular Western individualism. This worldview is determining the (democratic) political ideals and the (neo-capitalist free market) economic views of the African Renaissance. It fits into the politico-economic globalisation propagated by the powerful Western world and its allies, like Japan. (For a description of the neo-capitalist free market ideology, see Van der Walt, 1999a:59-74.)

Because I firmly believe that no kind of development - including economic and political development - can be healthy development without an accountable culturally-based worldview foundation (cf. Van der Walt, 1999b and 2001:43-92 for details), this capitulation to a secular, Western model of development does not augur well for the future of our continent. Development can only be genuine development - enhancing the wellbeing of the whole human being and not only his/her material welfare - when it seriously takes into account the culture, worldview and religion of the people to be "developed". It is purely to our detriment to ignore the fact that Africa is not identical to the West and therefore needs its own indigenous way of development.

As Christians we cannot accept this state of affairs, especially because of the large and still growing number of Christians not only in South Africa, but in the whole subcontinent. Christians can and should play a vital role in the African Renaissance and make a difference. The question is how? 


\section{The way ahead}

What, then, should our attitude as Christians be towards the African Renaissance? To my mind it should be the same as that of the Reformers during the European Renaissance. They did not isolate themselves from the Renaissance movement of their times but fully participated in efforts for renewal. They learned from the classical humanists. Much can be learned from Mbeki's renaissance vision. He puts his finger on the things that really matter, the really vital issues confronting our continent, which cannot be said about most types of Christianity on our continent.

\subsection{Escapism and pietism}

I have heard some Christians saying that Mbeki's effort reminds them of the typical humanist who tries to pull himself from the morass by his own bootstraps. This contains some truth, but Christians in Africa are often guilty of the opposite mistake: They sit back in complacency or at most they pray to God to intervene, without rolling up their sleeves and dirtying their hands.

We cannot ignore the fact that perhaps the dominant type of Christianity on our continent is of an escapist and pietist nature (Van der Walt, 2001:18-20,103-104). Christian faith like that is something of another world, without any relevance to the burning issues of Africa. However, if we want a new Africa, we need a new type of Christianity (Van der Walt, 1999a:1-22).

\subsection{Religion and society}

Many are of the opinion that religion does not make any difference in society. Others believe that it does have an impact, but a negative one. Still others think that the influence of religion has to be limited to private life and the church. According to the Reformational worldview, however, life is religion. As humans we are religious beings, being either gripped by the true God or something in creation elevated to a divine position. We either obey God's commandments or we obey the instructions of the idol we worship - and we create a society according to our own image.

If we follow these three steps backward, it is possible to determine from the type of society we have, firstly, how we view human beings and, secondly, the image of the God we serve. Societal life is thus a reflection of deep religious commitment, which also applies to a secular society.

Because religion is a fallible, human response to what is regarded as divine, it can be used wrongly and Christians in the past have done evil 
things in the name of Christ (cf. apartheid ideology). But it is just as true that Christianity can be a powerful force for the reformation of every aspect of life.

\subsection{The need of a Christian worldview}

Why then does Christianity, in spite of its numbers, have so little impact on society? One of the main reasons is the lack of a deep, broad and inspiring Christian worldview. To be a reborn Christian and to go to church is not enough, we need to open our eyes, broaden our vision so that we can know how to serve God fully.

The outline of such a worldview was formulated long ago by the great African thinker, Aurelius Augustine (354-431), reformulated by John Calvin (1509-1564) and refined by many Reformational thinkers during following centuries. Its essence is that a Christian should not try to live against, alongside or above the world but in order to renew and transform it, the Christian should be present in the world. 6

According to the Medieval worldview (see above) Christians had to choose between God and the world. According to a Reformational worldview, this is a false choice. We have to serve God in his creation!

Thus the maturation of African Christianity, a genuine renaissance, urgently requires the creation of written sources to nourish such an allencompassing Christian-Reformational worldview. These written sources must come from the pens and computers of Africans themselves. We need a whole new corpus of Christian writings that will address the burning issues of Africa in the 21st century from a Reformational perspective. We need a new generation of African reformers - a contemporary Augustine and Calvin. They should help us ensure that this new century is not merely an African century but a century belonging to God. If Christ is not King of all, He is not King at all!

\section{Bibliography}

BEDAIKO, K. 2001. The African Renaissance and theological reconstruction. Journal of African Christian Thought, 4(2):29-33, Dec.

BOUWSMA, W.J. 1988. John Calvin; a sixteenth-century portrait. New York/Oxford :

Oxford University Press.

6 The title of a recent book by Paul Marshall and Gilbert (1998) states it negatively: Heaven is not my home: living in the now of God's creation. It could also be stated positively as is the case with an earlier book by Al Wolters (1985): Creation regained; Biblical basics for a Reformational worldview. 
DE SANTILANA, G. 1956. The age of adventure; the Renaissance philosophers. New York: The New American Library.

ESTEP, W.R. 1986. Renaissance and Reformation. Grand Rapids, Michigan : Eerdmans.

GANOCZY, A. 1987. The young Calvin. Philadelphia, Pennsylvania : Westminster.

GYEKYE, K. 1997. Tradition and modernity; philosophical reflections on the African experience. Oxford : Oxford University. Press.

KOMBO, J. 2000. The African Renaissance as a new context for African Evangelical Theology. African Journal of Evangelical Theology, 19(1):3-24.

LANDSBERG, C. \& HLOPE, D. 1999. (October). African Renaissance as a modern South African foreign policy statement. http://www.ceri-sciences-po.org. (Date of access: $11 / 01 / 2002$.)

LIEBENBERG, I. 1998. The African Renaissance: myth, vital lie or mobilising tool? African Security Review, 7(3):40-52.

MAKGOBA, M.W., ed. 1999. African Renaissance; the new struggle. Sandton/ Mafube \& Cape Town : Tafelberg.

MANA, K. 2001. Christians and churches of Africa envisioning the future, salvation in Christ and the building of a new African society. Journal of African Christian Thought, 4(2):8-18, Dec.

MARSHALL, P. \& GILBERT, L. 1998. Heaven is not my home; living in the now of God's creation. Nashville : Word Publishing.

MBEKI, T. 1998. Africa; the time has come. Kaapstad/Mafube/Johannesburg : Tafelberg. (See chapters 4, 28, 32, 34 and 42.)

MBEKI, T. 1998a. The African Renaissance statement of deputy president, Thabo Mbeki, Gallagher Estate, 13 Aug. 1998. http://www.go.za. (Date of access: 11/01/2002.)

MBEKI, T. 1998b. Statement by deputy president Mbeki at the African Renaissance Conference, Johannesburg, 28 Sept. 1998. http://www.go.za. (Date of access: 11/01/2002.)

MBEKI, T. 1999. Speech at the launch of the African Renaissance Institute, Pretoria, 11 Oct. 1999. http://www.go.za. (Date of access: 11/01/2002.)

MBEKI, T. 2000a. Democracy and Renaissance in Africa; in search of an enduring Pax Africana. Nigerian Institute for International Affairs, Abuja, 3 Oct. 2000. http://www.go.za. (Date of access: 11/01/2002.)

MBEKI, T. 2000b.The African Renaissance; the challenge of our time. Address to the Ghana-South Africa Friendship Association, Accra, 5 Oct. 2000. http://www.go.za. (Date of access: 11/01/2002.)

MBEKI, T. 2001. Briefing on Millennium African Renaissance Program. WEFmeeting, Davos, 28 Jan. 2001. http://www.go.za. (Date of access: 11/01/2002.)

MBEKI, T. 2002. Address of President Thabo Mbeki at the 90th anniversary of the African National Congress, Durban, 6 Jan. 2002. http://www.go.za. (Date of access: 11/01/2002.)

McGRATH, A.E. 1988. Reformation thought; an introduction. Oxford : Blackwell.

MZAMANE, M.V. 2001. Where there is no vision the people perish; reflections on the African Renaissance (2001). http://www.unisa.edu.au/hawke/institute/working. (Date of access: 27/06/2002.)

PARIS, P.J. 2001. African spiritual values and the African Renaissance. Journal of African Christian Thought, 4(2):23-28, Dec.

PARTEE, C. 1977. Calvin and Classical philosophy. Leiden : Brill.

POPKIN, R.H., ed. 1966. The philosophy of the sixteenth and seventeenth century. New York : Free Press. 
RIENSTRA, H. 1981. The religious problem of the Renaissance. (In Van der Goot, $\mathrm{H}$., ed. Life is religion; essays in honor of $\mathrm{H}$. Evan Runner. St. Catherines, Ontario : Paideia Press. p. 45-60.)

STÖRIG, H.J. 1969. Geschiedenis van de Filosofie. Utrecht/Antwerpen : Het Spectrum.

VAN DER WALT, B.J. 1987. Biblical and unbiblical traits in Calvin's view of man. (In Van der Walt, B.J. Heartbeat; taking the pulse of our theological and philosophical heritage. Potchefstroom : IRS. p. 299-252.)

VAN DER WALT, B.J. 1991a. Renaissance and Reformation: contemporaries but not allies. (In Van der Walt, B.J. Anatomy of Reformation; flashes and fragments of a Reformational worldview. Potchefstroom : IRS. p. 201-208.)

VAN DER WALT, B.J. 1991b. Sixteenth century models for Christian involvement in the world. (In Van der Walt, B.J. Anatomy of Reformation. Potchefstroom : IRS. p. 154-200.)

VAN DER WALT, B.J. 1991c. The intellectual décor of the Reformation. (In Van der Walt, B.J. Anatomy of reformation. Potchefstroom : IRS. p. 209-256.)

VAN DER WALT, B.J. 1991d. Out of love for my church; on the reformation of a Reformed church. (In Van der Walt, B.J. Anatomy of reformation. Potchefstroom : IRS. p. 281-317.)

VAN DER WALT, B.J. 1994. The idea of reformation in the history of Christianity. (In Van der Walt, B.J. The liberating message; a Christian worldview for Africa. Potchefstroom : IRS. p. 320-325.)

VAN DER WALT, B.J. 1999a. Religion and society; Christian involvement in the public square. Potchefstroom : IRS.

VAN DER WALT, B.J. 1999b. Kultuur, lewensvisie en ontwikkeling. Potchefstroom : IRS.

VAN DER WALT, B.J. 2001. Transformed by the renewing of your mind; shaping a Biblical worldview and a Christian perspective on scholarship. Potchefstroom : The Institute for Contemporary Christianity in Africa.

WOLTERS, A.M. 1985. Creation regained; Biblical basics for a Reformational worldview. Grand Rapids : Eerdmans.

\section{Key concepts:}

Reformation - 16th century

Renaissance - European (1300-1600)

Renaissance - African

John Calvin (1509-1564)

Thabo Mbeki (1942 - )

\section{Kernbegrippe:}

Reformasie - 16de-eeuse

Renaissance - Europese (1300-1600)

Renaissance - Afrika

Johannes Calvyn (1509-1564)

Thabo Mbeki (1942- ) 